\title{
Jaminan Atas Pemenuhan Hak Keamanan Data Pribadi Dalam Penyelenggaraan E-Government Guna Mewujudkan Good Governance
}

\author{
Bunga Asoka Iswandari \\ Fakultas Hukum Universitas Indonesia Jakarta Indonesia \\ Jln. Prof. Mr. Djokosoetono, Kota Depok, Jakarta Indonesia 16424 \\ baiswandari@gmail.com
}

Received: 16 September 2020; Accepted: 27 November 2020; Published: 16 Maret 2021

DOI: 10.20885/iustum.vol28.iss1.art6

\begin{abstract}
This paper focuses on discussing the integration between the implementation of e-government as an alternative to public services with the principles of good governance and the existence of legal guarantees in the implementation of e-government that can fulfill the right to personal data for private information contained in the e-government system. The study was conducted using the library research data collection method and analyzed prioritizing logical thinking so as to find the cause and effect that will occur and this writing is a qualitative normative legal research. Bureaucratic reform to digital direction will be an improvement step for public services because through the digital bureaucracy the dream of realizing good governance in Indonesia becomes even more real. The electronization of communication between the public service sector and society, which is implemented with the existence of e-government, is an effort to create a digital bureaucracy. In practice, the egovernment system contains a lot of information, both public and private. Data security, which is private information from every community, is very important in relation to e-government, public trust will be greatly affected by data security issues. However, the laws and regulations in Indonesia do not yet regulate the protection of personal data. Whereas the security of a citizen's personal data is a right that must be fulfilled by the state, therefore the government must have a legal guarantee mechanism that can create a safe e-government system.
\end{abstract}

Key Words: E-government; good governance; personal data; right to security

\section{Abstrak}

Penulisan ini berfokus untuk membahas mengenai keterpaduan antara penyelenggaraan e-government sebagai alternatif pelayanan publik dengan prinsip-prinsip good governance serta keberadaan jaminan hukum dalam penyelenggaraan e-government yang dapat memenuhi hak atas data pribadi untuk informasi privat yang termuat didalam sistem e-government. Studi dilakukan dengan menggunakan metode pengumpulan data studi kepustakaan dan dianalisa mengutamakan pemikiran secara logika sehingga menemukan sebab akibat yang akan terjadi serta penulisan ini merupakan penelitian hukum normatif yang bersifat kualitatif. Reformasi birokrasi ke arah digital akan menjadi langkah perbaikan bagi pelayanan publik karena melalui birokrasi digital impian untuk mewujudkan good governance di Indonesia menjadi kian nyata. Elektronisasi komunikasi antara sektor pelayanan publik dan masyarakat yang diimplementasikan dengan adanya e-government merupakan salah satu upaya untuk menciptakan birokrasi digital. Dalam pelaksanaannya, sistem e-government memuat banyak informasi baik yang bersifat publik maupun privat. Keamanan data yang sifatnya informasi privat dari setiap masyarakat merupakan hal yang sangat penting terkait dengan e-government, kepercayaan masyarakat akan sangat terpengaruh oleh perihal kemanan data. Namun peraturan perundang-undangan di Indonesia belum mengatur mengenai perlindungan data pribadi. Padahal keamanan data pribadi seseorang warga negara merupakan suatu hak yang harus dipenuhi oleh negara, oleh karena itu pemerintah harus memiliki mekanisme jaminan hukum yang dapat menciptakan sistem e-government yang aman.

Kata-kata Kunci: Hak keamanan; data pribadi; e-government; good governance 


\section{Pendahuluan}

Pembangunan pelayanan publik menjadi suatu titik strategis untuk menciptakan good governance yang efektif dan efisien. Hal ini dikarenakan pelayanan publik melibatkan kepentingan semua unsur pemerintahan yakni pemerintah sebagai representasi dari negara, masyarakat sipil, serta para pelaku usaha yang memiliki pengaruh terhadap mekanisme pasar. Teknologi informasi dan komunikasi (TIK) yang sangat berkembang saat ini dapat memberikan jalan yang mudah untuk dapat memperbaiki pelayanan publik untuk mencapai penyelenggaraan pemerintahan sesuai dengan prinsip-prinsip good governance yang berjalan efektif dan efisien. Penggunaan TIK dapat mendukung pembangunan pelayanan publik dengan adanya reformasi birokrasi berbasis digital. Di Indonesia, penyelenggaraan urusan pemerintahan berbasis digital atau yang dikenal sebagai sistem e-government sudah mulai diterapkan. Masalah terbesar dari setiap pemanfaatan TIK adalah persoalan keamanan "privacy" sehingga sistem elektronik yang digunakan terutama sistem yang terkait dengan banyak orang harus mempunyai kelayakan dalam menjamin perlindungan data pribadi tidak terkecuali pada pelaksanaan e-government. ${ }^{1}$ Keamanan pada sektor publik terutama dalam penerapan sistem e-government merupakan hal yang perlu diperhatikan pemerintah karena merupakan hal sensitif sebab rentan disalahgunakan oleh pihak yang tidak berhak dan akan berpengaruh pada kepercayaan publik pada pelaksanaannya. Pelanggaran-pelanggaran pada data pribadi seseorang tidak hanya terjadi pada media sosial, akan tetapi program egovernment yang diselenggarakan pemerintah juga memiliki potensi pelanggaran data pribadi terutama pada program e-government yang melibatkan pihak swasta seperti program Kartu Tanda Penduduk Elektronik (e-KTP). ${ }^{2}$ Sekitar 1.227 lembaga baik lembaga pemerintahan maupun lembaga swasta telah diberikan akses data kependudukan dari KTP elektronik yang dimiliki seorang warga negara oleh Kementerian Dalam Negeri, namun setiap warga negara yang memiliki e-KTP tidak memiliki jaminan agar data pribadi mereka yang dapat

${ }^{1}$ Danrivanto Budhijanto, Revolusi Cyberlaw Indonesia Pembaharuan dan Revisi UU ITE 2016, Refika Aditama, Bandung, 2016, hlm.140.

2 Sinta Dewi Rosadi, Cyberlaw Aspek Data Privasi Menurut Hukum Internasional, Regional, dan Nasional, Refika Aditama, 2015, hlm. 12. 
diakses 1.227 lembaga tersebut tidak akan disalahgunakan. ${ }^{3}$ Walaupun persoalan data pribadi merupakan hal yang sangat penting, Indonesia hingga saat ini tidak mempunyai pengaturan hukum mengenai perlindungan data pribadi secara khusus. Pemerintah seharusnya memberikan jaminan hukum yang tepat terhadap keamanan data pribadi sehingga pelayanan melalui sistem e-government yang diterapkan kedepannya memiliki keamanan yang cukup sehingga masyarakat dapat percaya dengan reformasi birokrasi berbasis digital yang sedang dibangun oleh pemerintah.

Penerapan e-government bila dilihat dari tujuannya dirasa memberikan manfaat yang besar bagi reformasi birokrasi dalam pelaksanaan pelayanan publik terutama pada masa seperti ini dimana di 2020 terdapat pandemi covid-19 yang memaksa semua kegiatan kehidupan berubah. Dengan adanya e-government, pandemi covid-19 bukan menjadi suatu halangan bagi pemerintah untuk dapat memberikan layanan kepada masyarakat karena dengan pelayanan publik melalui e-government dapat terus dilaksanakan tanpa mengharuskan seseorang untuk datang secara fisik ke kantor-kantor instansi pemerintah. ${ }^{4}$ Instruksi Presiden No. 3 Tahun 2003 tentang Kebijakan dan Strategi Nasional Pengembangan E-Government merupakan langkah awal pemerintah sebagai bentuk kesungguhan pemerintah untuk menyelenggarakan pemerintahan dengan memanfaatkan sarana TIK yang tersedia. Pemerintah memberi petunjuk kepada para pejabat lembaga untuk mengambil langkah demi terlaksananya e-government secara nasional serta melekakukan perumusan dan pelaksanaan rencana tindak lanjut atas instruksi yang telah diberikan dan berkordinasi dengan Menteri Negara Komunikasi dan Informasi, dan melaksanakan instruksi dengan sebaikbaiknya. ${ }^{5}$ Pada setiap negara, tujuan penerapan e-government memiliki prioritas yang berbeda-beda seperti Portugal yang menerapkan e-government guna mewujudkan masyarakat yang demokratis dengan mendekatkan masyarakat

\footnotetext{
${ }^{3}$ BBC News Indonesia, Data KTP elektronik diserabkan ke lebih 1.200 lembaga pemerintah dan swasta, bagaimana upaya menjamin privasi ?, <https://www.bbc.com/indonesia/indonesia-49103924>, diakses pada 17 September 2020 .

4 Maya Septiani, E-Government Sebagai Strategi dalam Meminimalisasi Penyebaran Covid-19 dan Efektivitas Pelayanan Publik, < $\quad$ https://ombudsman.go.id/artikel/r/artikel--e-government-sebagai-strategi-dalammeminimalisasi-penyebaran-covid-19-dan-efektivitas-pelayanan-publik $>$, diakses 7 Juli 2020.

${ }^{5}$ Instruksi Presiden tentang Kebijakan dan Strategi Nasional Pengembangan E-Government, (Indonesia, Inpres No. 3 Tahun 2003).
} 
kepada negara melalui TIK. Singapura menerapkan e-government sebagai upaya untuk meningkatkan image sebagai penghubung e-commerce untuk berbagai negara. Tujuan sederhana dari e-government di Indonesia adalah agar di dalam pemerintahan tercipta koordinasi yang baik, serta akan lahir aksesibilitas yang lebih mudah untuk pelayanan publik, sehingga masyarakat dapat merasakan demokratisasi bisa hidup ditengah mereka. E-government di Indonesia memiliki tujuan untuk menghubungkan pemerintah dengan para stakeholders baik Government to Citizen, Government to Business, dan bahkan Government to Government semua stakeholders memegang peran penting dalam pelakasanaan sistem pemerintah berbasis elektronik ini.

E-government merupakan suatu dukungan bagi penerapan revolusi industri 4.0 yang menjadi suatu inovasi dalam dunia pemerintahan sebagai bukti nyata atas kemajuan TIK yang semakin pesat. Kemajuan TIK yang terjadi mengakibatkan berbagai perubahan pada peradaban manusia secara global dan memberikan perubahan sosial yang secara signifikan dan berlangsung dengan cepat. ${ }^{6}$ Akan tetapi, penggunaan kemajuan TIK yang berbasis pada penggunaan internet dapat berpotensi buruk pada penyalahgunaan yang dilakukan oleh pihak yang tidak bertanggungjawab sehingga menyebabkan kerugian bagi perorangan, atau bagi sektor swasta, bahkan bagi pertahanan dan keamanan negara atau keamanan nasional.

Di Indonesia sendiri, walaupun sudah menerapkan sistem e-government namun belum ada kebijakan yang menjamin atas perlindungan data terutama data pribadi yang ada pada sistem e-government. ${ }^{7}$ Data pribadi adalah data perseorangan tertentu yang disimpan, dirawat, dan dijaga kebenaran serta dilindungi kerahasiaannya. ${ }^{8}$ Dalam perjalanan hidup seseorang data pribadi sudah mulai muncul dari sejak seseorang lahir hingga kemudian meninggal. Data-data pribadi pribadi seseorang tersebut sebagian besar terserap dan tersimpan serta terkelola oleh sejumlah instansi atau lembaga pemerintahan sebagai contoh ketika seseorang lahir ke dunia memerlukan akta kelahiran dan

\footnotetext{
${ }^{6}$ Ahmad M. Ramli, Cyber Law \& HAKI dalam Sistem Hukum Indonesia, Bandung, Refika Aditama, 2004.

${ }^{7}$ Lestarri Moerdijat, Perlindungan Data Pribadi, <http://lestarimoerdijat.com/2019/10/05/perlindungandata-pribadi/>, diakses 16 Maret 2020

8 Indonesia, Undang-Undang tentang Perubahan atas Undang-Undang Nomor 23 Tahun 2006 tentang Administrasi Kependudukan, UU No. 24 Tahun 2013, LN No. 232 Tahun 2013, TLN. No. 5475, Ps. 1.
} 
ketika seseorang mati perlu adanya akta kematian untuk dicatatkan. ${ }^{9}$ Sebenarnya sudah banyak peraturan yang membahas mengenai perlindungan data pribadi namun Indonesia belum memiliki peraturan perundang-undangan yang secara khusus mengatur mengenai perlindungan data pribadi sehingga memungkinkan aturan yang sudah ada akan saling tumpang tindih. Data pribadi merupakan privasi seseorang dimana privasi merupakan bagian dari hak asasi manusia, sehingga perlindungan data pribadi khususnya data yang ada pada sistem $e$ government sebagai hak penting yang dimiliki seseorang. Keberadaan teknologi memiliki harapan besar sebagai infrastruktur utama untuk meningkatkan kecepatan pada pelayanan publik yang dilakukan oleh pemerintah sehingga dapat meningkatnya kualitas pelayanan. Pelayanan publik merupakan suatu hal yang sangat mendasar bagi instansi pemerintah sebagai pelayan masyarakat yang memiliki kewajiban dan tanggung jawab untuk memberikan pelayanan yang baik dan professional. ${ }^{10}$

Potensi pelanggaran hak privasi ada pada setiap sistem yang bersifat on-line dan pada sistem yang melakukan pengumpulan data pribadi secara masal (digital dossier) contohnya saja dalam pelaksanaan program e-KTP atau segala bentuk pelaksanaan sistem e-government lainnya. Masyarakat mengharapkan ada kepastian hukum dari pemerintah, karena sudah menjadi kewajiban pemerintah untuk menjamin hak-hak dari masyarakatnya demi menjalankan prinsip good governance. Komitmen semua tingkatan di jajaran pemerintahan, khususnya di tingkat pimpinan merupakan faktor yang sangat diperlukan dan juga sebagai faktor kunci penentu keberhasilan dalam pembangunan dan penerapan TIK di pemerintahan dengan semangat untuk melindungi segenap bangsa dan seluruh tumpah darah Indonesia sesuai dengan cita-cita yang termaktub dalam pembukaan Undang-Undang Dasar Negara Republik Indonesia Tahun 1945.

Berdasarkan uraian diatas, terdapat permasalahan mengenai pemenuhan hak atas jaminan hukum terhadap data pribadi dalam penyelenggaraan e-

9 Muhammad Faiz Aziz, Data Pribadi: Meneropong Kerangka Perlindungan Data Pribadi di Indonesia, < https://bahasan.id/data-pribadi-meneropong-kerangka-perlindungan-data-pribadi-di-indonesia/>, diakses 9 Juli 2020 .

10 Arif Cahyadi, "Penerapan Good Governance Dalam Pelayanan Publik", Jurnal Penelitian Administrasi Publik, Vol. 2 No. 2, 2016, hlm. 479. 
government yang harus dilakukan pemerintah agar e-government dapat sebagai alternatif pelayanan publik dengan sesuai dengan prinsip-prinsip good governance. Oleh karena itu penulis tertarik untuk membahas tentang Jaminan Atas Pemenuhan Hak Keamanan Data Pribadi Dalam Penyelenggaraan Urusan Pemerintahan Berbasis Elektronik (E-Government) Berdasarkan Prinsip-Prinsip Good Governance.

\section{Rumusan Masalah}

Rumusan masalah dalam penelitian sebagai berikut. Pertama, bagaimana keterpaduan antara penyelenggaraan e-government sebagai alternatif pelayanan publik dengan prinsip-prinsip good governance? Kedua, bagaimanakah jaminan hukum terhadap pemenuhan hak atas data pribadi dalam penyelenggaraan $e$ government?

\section{Tujuan Penelitian}

Tujuan umum dalam penelitian ini membahas mengenai jaminan atas pemenuhan hak keamanan data pribadi dalam penyelenggaraan urusan pemerintahan berbasis elektronik (e-government) berdasarkan prinsip-prinsip good governance. Sedangkan tujuan khusus dalam penelitian adalah untuk mengetahui keterpaduan antara penyelenggaraan e-government sebagai alternatif pelayanan publik dengan prinsip-prinsip good governance dan menjelaskan jaminan hukum terhadap pemenuhan hak atas data pribadi dalam penyelenggaraan e-government.

\section{Metode Penelitian}

Jenis penelitian yang digunakan dalam penulisan hukum ini adalah penelitian hukum normatif. Pendekatan yang digunakan adalah pendekatan kualitatif. Metode pengumpulan bahan hukum yang akan digunakan dalam penelitian hukum yang akan digunakan dalam penelitian hukum ini adalah studi dokumen atau studi kepustakaan (library research). Jenis data yang digunakan dalam penelitian ini adalah data sekunder karena bentuk penelitiannya berupa penelitian yuridis-normatif. Teknik analisis bahan hukum yang dipergunakan adalah analisis bahan hukum yang bersifat deduksi dengan metode silogisme. 


\section{Pembahasan dan Hasil Penelitian}

\section{Penyelenggaraan E-Government sebagai Alternatif Pelayanan Publik dengan Prinsip-Prinsip Good Governance}

Kenyataan terjadinya perkembangan ilmu pengetahuan dan teknologi yang semakin maju dan canggih harus dihadapi oleh para penyelenggara pelayanan publik di berbagai jenjang dan jalur, dimana pemerintah dituntut untuk bisa menyelenggarakan pemerintahan yang efisien dan efektif dengan penggunaan TIK. Birokrasi berbasis digital menjadi salah satu jawaban untuk mengurai kepelikan yang terjadi pada birokrasi di Indonesia sebagai penerapan reformasi birokrasi yang ingin dilakukan. Menurut Dwiyanto reformasi birokrasi merupakan suatu upaya untuk melakukan perubahan secara fundamental dan menyeluruh dalam bidang pemerintahan, terutama dalam bidang sumber daya manusianya atau birokratnya untuk menghasilkan tatanan pemerintahan yang baik, memiliki karakteristik, peduli, professional, berintegritas, mampu menyelenggarakan pelyanan yang unggul, berperan sebagai agen pembaharu, dan berkontribusi dalam mewujudkan pemerintahan yang demokratis. ${ }^{11}$

Pelayanan publik merupakan hal yang sangat penting dalam penyelenggaraan pemerintahan. Pelayanan publik adalah kegiatan atau rangkaian kegiatan dalam rangka pemenuhan kebutuhan pelayanan sesuai dengan peraturan perundangundangan bagi setiap warga negara dan penduduk atas barang, jasa, dan/atau pelayanan administratif yang disediakan oleh penyelenggara pelayanan publik. ${ }^{12}$ Konsep dari pelayanan tidak lepas dari kebutuhan masyarakat yang harus dipenuhi secara optimal oleh aparatur negara dalam mencapai tujuan pemerintahan yaitu good government. ${ }^{13}$ Selama ini pola pelayanan publik selalu memiliki sifat kurang partisipatif, kurang akuntabel, kurang efisien, dan juga membeda-bedakan. Pelayanan publik hanya menjadi ranah dimana negara yang diwakili oleh pemerintah berinteraksi dengan lembaga-lembaga non-pemerintah yang menyebabkan kurangnya keterlibatan

\footnotetext{
${ }^{11}$ Hayat, Kebijakan Publik (Evaluasi, Reformasi, dan Formulasi), Intrans Publishing, Malang, 2018, hlm. 61-62.

12 Indonesia, Undang-Undang tentang Pelayanan Publik, UU No. 25 Tahun 2009, LN. No. 112 Tahun 2009, TLN No. 5038, Ps. 1 ayat (1)

13 Ibid.
} 
masyarakat. ${ }^{14}$ Selain itu praktik korupsi, kolusi, dan nepotisme sering terjadi dalam birokrasi pelayanan publik yang menyebabkan birokrasi tersebut berjalan tidak efisien dan tidak transparan. Dengan berkembangnya infratsruktur yang dapat mendukung pelayanan e-government mendesak adanya pola pelayanan publik baru yang membawa kearah perbaikan agar pemerintahan menjadi semakin transparan dan efektif.

Masyarakat mengaharapkan layanan yang baik, mudah, murah, dan cepat serta transparan yang kemudian dikembangkanlah pelayanan publik yang dilakukan dengan basis digital dengan diterapkannya sistem e-government. Menurut The Worid Bank Group, e-government ialah sebagai upaya pemamfaatan informasi dan teknologi komunikasi untuk meningkatkan efesiensi dan efektivitas, transfaransi dan akuntabilitas pemerintah dalam memberikan pelayanan publik secara lebih baik. ${ }^{15}$ Menurut Richardus Eko Indrajit layanan $e$ government dapat dikelompokkan kedalam tiga jenis, pertama, jenis layanan yang bertujuan sebagai penyediaan informasi tentang pemerintah. Kedua, jenis layanan yang memiliki sifat komunikasi interaktif dua arah. Ketiga, jenis layanan yang memiliki sifat transaksi. ${ }^{16}$ Penerapan e-government yang dilakukan suatu negara dilakukan karena suatu negara tersebut percaya dengan melibatkan TIK didalam pemerintahan akan memberikan beberapa manfaat seperti untuk meningkatkan kualitas pelayanan yang diberikan pemerintah untuk masyarakat dan komunitas negara lainnya, memperbaiki transparansi dan akuntabilitas dalam penyelenggara pemerintah, mengurangi biaya transaksi, komunikasi, dan interaksi yang terjadi untuk kegiatan pemerintahan, menciptakan masyarakat yang berkualitas dengan berbasis komunitas informasi. ${ }^{17}$

Penerapan sistem informasi yang memanfaatkan kemajuan teknologi berbentuk e-government dilakukan oleh pemerintah untuk menunjang

\footnotetext{
14 Yasonna H. Laoly, Birokrasi Digital, Pustaka Alvabet, Jakarta, 2019, hlm. 199.

${ }^{15}$ Falid Suaedi dan Bintoro Wardiyanto, Revitalisasi Administasi Negara, Reformasi Birokerasi, dan E-Governance, Graha Ilmu, Yogyakarta, 2010, hlm. 54.

16 Nurcahyani Dewi Retnowati dan Daru Retnowati, "Peranan E-Government Dalam Rangka Mewujudkan Good Governance Bagi Masyarakat", Seminar Nasional Informatika 2008, UPN "Veteran” Yogyakarta, 24 Mei 2008.

${ }^{17}$ Richardus Eko Indrajit, et.al., e-Government In Action (Ragam Kasus Implementasi Sukses di Berbagai Belahan Dunia), Andi, Yogyakarta, 2005, hlm. 4.
} 
terlaksananya good government governance. ${ }^{18}$ Good Governance pada dasarnya berkaitan dengan penyelenggaraan tiga tugas dasar pemerintahan, yaitu: tugas untuk menjamin kemanan setiap orang dan masyarakat, tugas untuk mengelola suatu struktur yang efektif untuk sektor publik, sektor swasta dan masyarakat, dan tugas untuk memajukan sasaran ekonomi, sosial dan bidang lainnya dengan kehendak rakyat. ${ }^{19}$ Worlf Bank menggamnarkan good governance sebagai sebuah pemerintahan yang memiliki karakteristik mencakup akuntabilitas dan transparansi, efisiensi dalam menjalankan fungsi pemerintah, melakukan supremasi hukum, dan memiliki sistem politik yang stabil. ${ }^{20}$ Lembaga Administrasi Negara (LAN) menyebutkan ada sembilan unsur fundamental yang menjadi karakteristik dari good governance. ${ }^{21}$ Pertama, unsur partisipasi, ini berarti setiap warga negara mempunyai suara dalam pembuatan keputusan baik secara langsung maupun tidak. Kedua, adalah penegakan hukum, hukum harus dilaksanakan secara adil dan tanpa membeda-bedakan. Ketiga, transparansi, proses-proses serta informasi-informasi terkait institusi pemerintahan secara langsung harus dapat diterima, dipahami, serta dimonitor oleh setiap masyarakat. Keempat, adalah responsif, dimana lembaga-lembaga serta institusi-institusi pemerintah harus mencoba untuk dapat melayani setiap stakeholders. Kelima, adalah orientasi konsensus, berarti good governance menjadi perantara kepentingan yang berbeda untuk memperoleh pilihan-pilihan terbaik bagi kepentingan yang lebih luas dalam hal kebijakan. Keenam, adalah kesamaan, setiap individu masyarakat memiliki kesempatan yang sama untuk dapat meningkatkan atau menjaga kesejahteraan mereka. Ketujuh, efektifitas dan efisien, setiap kegiatan pemerintah melalui institusi-institusi pemerintah harus dijalankan sebaik mungkin. Kedelapan, adalah akuntanbilitas, dalam setiap keputusan yang diambil oleh pemerintah, para pembuat keputusan harus dapat bertanggungjawab kepada seluruh stakeholders. Kesembilan, adalah visi strategi,

18 Toni Heryana dan Sari Kartika Dewi, "Pengaruh Penerapan E-Government Terhadap Pelaksanaan Tata Kelola Pemerintahan Kabupaten Cianjur", Jurnal Riset Akuntansi dan Keuangan, Vol. 1 No. 1, 2013, hlm. 39.

19 Philipus M. Hadjon, Hukum Administrasi Sebagai Instrumen Hukum Untuk Mewnjudkan Good Governance, dalam Muhadi (ed), Hukum Administrasi dan Good Governance, Universitas Trisakti, Jakarta, 2012, hlm.9.

20 Grindle dalam Amy Y.S. Rahayu dan Vishnu Juwono, Birokrasi \& Governance Teori, Konsep, dan Aplikasinya, PT RajaGrafindo Persada, Depok, 2019, hlm. 67.

21 Arif Cahyadi, "Penerapan Good Governance Dalam Pelayanan Publik", Jurnal Penelitian Administrasi Publik, Vol. 2 No. 2, 2016, hlm. 480-481. 
para stakeholders harus memiliki perspektif good governance dan pengembangan manusia yang luas dan jauh kedepan sejalan dengan apa yang diperlukan untuk pembangunan.

Good governance dalam birokrasi dalam melakukan pengembangan tata kelola pemerintahan karena reformasi birokrasi memiliki tujuan yang sejalan dengan karakteristik good governance. Hal ini dapat dilihat dengan adanya Grand Design Reformasi Birokrasi yang memiliki target di 2025 akan terwujud tata pemerintahan yang baik dengan birokrasi pemerintah yang professional berintegritas tinggi, dan menjadi pelayan masyarakat dan abdi negara. Sesuai dengan visi reformasi birokrasi untuk mewujudkan pemerintahan kelas dunia yang professional dan berintegritas tinggi yang mampu menyelenggarakan pelayanan prima kepada masyarakat dan manajemen pemerintahan yang demokratis agar mampu menghadapi tantangan pada abad ke-21 melalui tata pemerintahan yang baik pada 2025.22 Peningkatan pelayanan publik merupakan bagian dari reformasi birokrasi. Peningkatan pelayanan publik minimal memenuhi lima persyaratan yaitu, pertama mendorong masyarakat untuk berpartisipasi dalam pengambilan keputusan baik langsung maupun tidak, kedua mengupayakan adanya saling percaya di antara masyarakat, ketiga kemampuan untuk menyikapi setiap masalah yang timbul serta kemampuan untuk menampung aspirasi dan keluhan masyarakat secara tepat tanpa ada perbedaan, keempat profesionalisme pemerintah sehingga mampu melayani publik secara mudah, cepat, akurat, dan sesuai permintaan, kelima akuntabilitas dari setiap kebijakan publik. ${ }^{23}$

Manfaat dari e-government bila dilihat dari Instruksi Presiden No. 3 Tahun 2003 disebutkan bahwa e-government ditujukan untuk meningkatkan efisiensi, efektifitas, transparansi dan akuntabilitas penyelenggaraan pemerintahan. Sistem pemerintahan berbasis elektronik ini ditujukan untuk mendorong serta mewujudkan penyelenggaraan pemerintahan yang terbuka, inovatif, akuntabel, dan partisipatif, guna meningkatkan kerjasama instansi-instansi pemerintah dalam melakukan urusan dan tugas pemerintahan untuk mencapai tujuan

22 Grand Design Reformasi Birokrasi 2010-2025.

${ }^{23}$ Hayat, Kebijakan Publik (Evaluasi, Reformasi, dan Formulasi), Intrans Publishing, Malang, 2018, hlm. 95. 
bersama, meningkatkan jangkauan serta kualitas dari pelayanan publik yang diberikan kepada masyarakat, dan untuk mencegah terjadinya tindakan penyalahgunaan kewenangan dalam bentuk kolusi, korupsi, dan nepotisme dengan adanya penerapan sistem pengawasan dan pengaduan masyarakat berbasis elektronik. Pelayanan secara on-line yang langsung kepada masyarakat dapat mengurangi kemungkinan terjadinya kegiatan korupsi dikarenakan tidak terjadinya tatap muka secara langsung antara masyarakat dengan penyelenggara pemerintah. Dengan sistem ini masyarakat diharapkan dapat langsung berpatisipasi untuk memantau pelayanan publik yang ada di setiap birokrasi instansi pemerintahan. Pelayanan seperti pengurusan SIM, STNK, IMB, SIUP, etilang dan semua pelayanan publik lainnya akan menjadi lebih mudah dan hal ini tentu sebagai bagian dari digitalisasi birokrasi. ${ }^{24}$ Dalam instruksi Presiden, penerapan sistem e-government diinstruksikan kepada seluruh entitas pemerintahan. Maka selain Pemerintah Pusat, semua Pemerintah Daerah juga ikut berlomba memberikan pelayanan menerapkan sistem e-government tersebut. ${ }^{25}$

Dilihat dari tujuan reformasi birokrasi dalam bentuk peningkatan pelayanan publik melalui penerapan e-government memiliki tujuan yang sama dengan yang diinginkan dalam penerapan good government. Untuk dapat menciptakan sistem $e$ government yang dapat merwujudkan penyelenggaraan good governance, egovernment harus memiliki visi yang jelas dalam pengembangannya serta pemimpin yang berkomitmen dalam pelaksanaanya. Visi yang baik di dalam $e$ government memiliki sejumlah karakteristik sebagai berikut:26

a) Visi disusun bersama dengan para stakeholders e-government karena egovernment ditujukan untuk kepentingan bersama. Selain itu visi yang dibuat secara bersama-sama tersebut memiliki tujuan agar terciptanya dukungan dari berbagai pihak yang berkepentingan agar dalam pelaksanaannya tidak mengalami hambatan yang berarti serta semakin banyak pihak yang turut mensosialisasikan konsep dari e-governement.

\footnotetext{
24 IT Governance Indonesia, Tata Kelola Sistem Pemerintahan Berbasis Elektronik, < https://itgid.org/perpres-sistem-pemerintahan-berbasis-elektronik-e-government-menjawab-tantanganrevolusi-4-0-untuk-wujudkan-tata-kelola-pemerintah-dan-pelayanan-publik-transparan-dan-modern/>, diakses 16 Maret 2020.

25 Toni Heryana dan Sari Kartika Dewi, "Pengaruh Penerapan E-Government Terhadap Pelaksanaan Tata Kelola Pemerintahan Kabupaten Cianjur", Jurnal Riset Akuntansi dan Keuangan, Vol. 1, No. 1, 2013, hlm. 39

${ }^{26}$ Richardus Eko Indrajit, et.al., e-Government In Action (Ragam Kasus Implementasi Sukses di Berbagai Belaban Dunia), Andi, Yogyakarta, 2005, hlm. 6.
} 
b) Visi yang dikembangkan bermuara pada pemberian pelayanan kepada masyarakat yang lebih baik sehingga harus berfokus pada kepentingan masyarakat. E-government memiliki tujuan akhir untuk memenuhi keberagaman dari masyarakat dalam rangka meningkatkan kualitas kehidupan manusia.

c) Visi harus secara mudah dikomunikasikan dan disosialisasikan agar seluruh masyarakat dapat mengerti dan memahami esensi e-government yang ingin diciptakan.

Namun penerapan e-government bukan hanya sekedar menjadi jalan pintas untuk menuju pencapaian efisiensi kinerja pemerintahan dalam waktu singkat. $E$ government merupakan sarana yang memerlukan proses kerja keras didalamnya. Penerapan e-government harus memperhatikan kebutuhan apa yang menjadi prioritas utama dari masyarakat di negara atau daerah terkait, serta memperhatikan ketersediaan sumber daya yang terdapat pada domain masyarakat dan pemerintahan tersebut. ${ }^{27}$ Partisipasi masyarakat dan pelaku usaha dalam penerapan pelayanan publik berbasis digital sangat diperlukan agar secara bersama dapat mewujudkan layanan publik yang semakin professional dan berkualitas demi mewujudkan good governance, saling bersinergi membangun pelayanan publik yang cepat, akurat, dan menyenangkan. ${ }^{28}$

\section{Jaminan Hukum terhadap Pemenuhan Hak atas Data Pribadi dalam Penyelenggaraan E-Government}

Semakin berkembangnya infrastruktur TIK juga telah banyak melahirkan inisiatif baru dalam penikmatan hak asasi manusia, khususnya hak atas informasi. Seperti desakan agar pemerintah suatu negara semakin terbuka, transparan, dan akuntabel, dengan menyediakan layanan infromasi melalui berbagai perangkat, yang dikemas dalam tema pemerintahan terbuka (open government). Sejumlah tantangan baru pun mengemuka seiring dengan berbagai macam kemudahan akses tersebut karena kian tipisnya pemisahan antara informasi yang sifatnya publik dan privat, juga masifnya perekaman data pribadi, baik yang dilakukan oleh pemerintah maupun swasta. Semakin menguatnya tuntutan dan inisiatif keterbukaan informasi juga telah melahirkan ketegangan

${ }^{27}$ Richardus Eko Indrajit, et.al., e-Government In Action (Ragam Kasus Implementasi Sukses di Berbagai Belahan Dunia), Andi, Yogyakarta, 2005, hlm. 7.

${ }^{28}$ Yasonna H. Laoly, Birokrasi Digital, Pustaka Alvabet, Jakarta, 2019, hlm. 143. 
baru dengan perlindungan hak atas privasi, khususnya data dan informasi pribadi warga negara. Kondisi kian perlindungan hak atas privasi Indonesia menambah permasalahan yang diakibatkan kekosongan peraturan yang ditujukan untuk perlindungan terhadap data pribadi. ${ }^{29}$ Birokrasi pelayanan selalu membutuhkan informasi mengenai warga yang menggunakan layanan beserta karakteristiknya agar birokrasi pelayanan dapat mengenali pengguna layanan dengan baik serta menyesuaikan jenis dan cara pemberian layanan sesuai dengan kebutuhan warga, selain itu informasi juga dapat membantu birokrasi pelayanan untuk mempermudah pengguna layanan publik untuk mengakses pelayanan publik. ${ }^{30}$

Pelayanan publik tidak bisa berjalan tanpa adanya kepercayaan dari publik, pada penerapan sistem e-government kepercayaan publik memiliki 8 variabel yaitu: 31

1. Kepercayaan pada data yang tersimpan bahwa data yang dikumpulkan dan disimpan akan dilindungi dari potensi ancaman penyalahgunaan data, perubahan data, dan penggunaan data oleh pihak yang tidak berkepentingan

2. Kepercayaan pada pelayanan akan cepat tanggap dalam menyelesaikan masalah.

3. Kepercayaan pada kualitas informasi bahwa informasi yang diberikan valid dan lengkap sehingga dapat diandalkan.

4. Kepercayaan pada sistem teknologi informasi e-government yang menggunakan operasi yang tepat.

5. Kepercayaan pada sistem transaksi berkaitan dengan kemanan dan perlindungan data serta integritas dan kerahasiaan.

6. Kepercayaan pada instansi pemerintah penyedia layanan e-government yang akan bertindak demi kepentingan masyarakat.

7. Kepercayaan pada institusi pendukung layanan e-government seperti penerpan hukum, kebijakan dan peraturan.

8. Kepercayaan pada teknologi yang disediakan.

Negara menjadi subjek hukum utama yang bertanggung jawab melindungi, menegakkan, dan memajukan hak asasi manusia, setidaknya untuk

${ }^{29}$ Institute For Justice Reform, Menyelaraskan Kebijakan Data Terbuka dan Perlindungan Hak Atas Privasi, $<$ https://icjr.or.id/menyelaraskan-kebijakan-data-terbuka-dan-perlindungan-hak-atas-privasi/ $>$, diakses tanggal 16 Maret 2020.

30 Agus Dwiyanto, Survei Warga Pengguna Layanan, dalam Agus Dwiyanto (ed), Mewrijudkan Good Governance Melalui Pelayanan Publik, Gadjah Mada University Press, Yogyakarta, 2014, hlm. 342.

31 Agus Purwanto dan Tony Dwi Susanto, "Pengaruh Dimensi Kepercayaan Terhadap Adopsi Layanan E-Government', INFORM, Vol. 3 No. 1, 2018, hlm. 13-14. 
warganegaranya masing-masing. Tetapi disadari atau tidak, pelanggaran hak asasi manusia malah seringkali terjadi justru bersumber dari kebijakan publik yang masih belum sepenuhnya memperhatikan parameter hak asasi manusia dalam penyusunannya dan hanya terfokus pada pencapaian sasaran pembangunan. Peningkatan pelayanan publik seharusnya tidak hanya sekedar memenuhi dokumen reformasi birokrasi namun harus berfokus pada pencapaian sasaran-sasaran reformasi yang bersifat substansial. ${ }^{32}$ Informasi yang dimiliki oleh pemerintah perlu dijamin kemanan dan kerahasiannya agar tidak disalahgunakan oleh pihak yang tidak berhak. Ada sejumlah besar potensial membahayakan keamanan yang dapat dengan mudah melumpuhkan dan merusak layanan e-government. Sebagian besar masalah keamanan dapat diklasifikasikan dalam empat kategori besar: ${ }^{33}$

a. Kemanan Infrastruktur

Jaringan data pemerintah menyediakan infrastruktur inti untuk interaksi tepat waktu antara lembaga dan berbagai unsur. Membangun dan mempertahankan tingkat keamanan jaringan yang tinggi adalah kunci untuk memastikan ketersediaan dari perhitungan infrastruktur yang menjadi dasar semua layanan informasi lainnya. Hal ini juga memastikan integritas informasi yang dikelola oleh pemerintah.

b. Kemanan Aplikasi

Pemerintah menurut tradisi telah menjadi pendukung penerapan keamanan aplikasi yang ketat. Namun, mengingat persyaratan akses publik yang lebih luas dari layanan e-Government, kerentanan harus dinilai kembali untuk menyeimbangkan dampak risiko potensial dengan langkah-langkah keamanan yang tepat.

c. Identifikasi Manajemen

Dengan meningkatnya jumlah transaksi elektronik tanpa tatap muka, pemerintah perlu mengatasi tantangan dalam mengelola akses yang dapat diidentifikasi ke informasi dan aplikasi yang tersebar di berbagai sistem komputasi internal dan eksternal. Selain itu, mereka harus melayani semakin banyak pengguna publik yang menuntut mekanisme akses yang tidak rumit, tanpa membahayakan keamanan, yang tanpa sengaja memungkinkan akses ke informasi sensitif.

d. Jaminan Informasi

Pemerintah harus menjadi pemelihara yang bertanggung jawab atas sejumlah besar informasi pribadi yang dipercayakan kepada mereka.

${ }^{32}$ Roby Arya Brata, Analisis Masalah Good Governance dan Pemerintahan Strategis, Pustaka Kemang, Jakarta, 2016, hlm. 233.

${ }_{33}$ James SL Young, Enabling Public Service Innovation in the 215t Century E-Government in Asia, Times Editions, Singapore, 2003, hlm. 340-341 
Program perangkat lunak, situs web, dan layanan harus memberikan perlindungan yang memadai terhadap akses tidak sah dan harus memastikan mereka menjalankan praktik perlindungan data dan privasi terbaik. Berbagi informasi antar lembaga juga harus dilakukan dengan kehati-hatian yang memadai untuk mencegah pelanggaran atas penggunaan informasi yang jauh dari sumbernya.

Menerapkan birokrasi berbasis digital berarti melakukan reformasi budaya juga yang awalnya dari tradisional menjadi modern. Perubahan dari konvensional menuju digital bukanlah suatu hal yang mudah untuk dihadapi dan disusun strateginya. Selalu banyak hambatan untuk menemukan formulasi penerapan yang terbaik sehingga dibutuhkan good will pemerintah untuk menerapkan sistem berbasis digital ini tetap dengan kuat dan secara konsekuen. Penerapan sistem dengan berbasis internet merupakan hal yang rentan dengan resiko kejahatan seperti hacker dan cyber crime. ${ }^{34}$ Terdapat enam komponen penting dalam penerpan e-government. Pertama adalah content development mengenai pengembangan perangkat yang digunakan. Kedua adalah competency building yang terkait dengan pengadaan sumber daya manusia. Ketiga adalah connectivity yaitu tentang infrastruktur TIK yang akan diterapkan. Keempat terkait dengan cyber laws yang menyangkut tentang kerangka dan perangkat hukum yang diberlakukan terkait penerapane-government. Kelima komponen citizen interfaces agar seluruh masyarakat dan stakeholders dapat menggunakan dimana saja dan kapan saja. Komponen keenam terkait dengan capital, bagaimana pola permodalan pada penerapan sistem e-government. ${ }^{35}$. Bila dilihat dari komponen penting bagi e-government, cyber laws menjadi salah satu komponen didalamnya. Salah satu negara yang mempunyai aturan tentang keamanan data untuk mendukung sistem e-governement adalah negara Colorado. Pemerintah Colorado mengeluarkan aturan tentang keamanan data dan penggunaan informasi yang didapatkan dari berbagai sistem informasi dalam program egovernment. Pemerintah Colorado menjamin bahwa informasi yang ada akan dipergunakan sebagaimana mestinya dan memberikan hukuman yang berat bagi pihak-pihak yang menyalahgunakan informasi tersebut. Negara Malta pun

\footnotetext{
34 Yasonna H. Laoly, Birokrasi Digital, Pustaka Alvabet, Jakarta, 2019, hlm. 256.

35 Bambang Irawan, "Studi Analisis Konsep E-Government. Sebuah Paradigma Baru dalam Pelayanan Publik", Jurnal Paradigmas Vol. 2 No. 1, 2013, hlm. 185.
} 
menyatakan perang terhadap segala bentuk kejahatan di dunia cyber dengan menyebarkan berbagai kampanye anti cyber crime, membangun mekanisme untuk penyelidikan dan penangkalan terhadap cyber crime, serta merekomendasikan pengambilan kebijakan tentang langkah-langkah yang diperlukan dalam pemberantasan cyber crime. ${ }^{36}$ Korea Selatan semenjak setiap lembaga pemerintahan dapat membangun dan mengoperasikan sistem e-government sendiri, untuk menanggapi serangan keamanan di setiap pengoperasiannya pemerintah Korea Selatan mendirikan pusat data terintegrasi sebagai fondasi untuk e-government yang andal dan berkelanjutan. ${ }^{37}$ Dalam pelaksanaan e-government di Korea Selatan ministry of the interior and safety Korea Selatan berafiliasi dengan lembaga pemerintahan non kementerian yang bernama National Information Resources Service. ${ }^{38}$

Keamanan data dan privacy masyarakat merupakan hal yang harus diperhatikan dan dipertimbangkan secara sungguh-sungguh di dalam penyelenggaraan birokrasi berbasis digital yang menggunakan internet. Karena indikator kualitas pelayanan salah satunya adalah kemampuan dan keandalan dalam menyediakan pelayanan yang terpecaya. ${ }^{39}$ Pembangunan dan pengembangan komponen-komponen pendukung pelaksana sistem e-government harus di rencanakan dengan memperhatikan berbagai aspek dengan melihat fakta dan kemungkinan yang akan terjadi. Informasi yang dimiliki oleh pemerintah terkait individu-individu dalam masyarakat perlu dijamin keamanan dan kerahasiaannya agar tidak jatuh ke orang yang tidak bertanggung jawab dan disalahgunakan oleh pihak yang tidak memiliki wewenang yang akan memiliki dampak yang sangat serius. Pemerintah perlu menjamin bahwa data masyarakat yang bersifat pribadi akan tetap aman dan tidak bocor kepada pihak-pihak yang tidak selayaknya mengetahui. Penyalahgunaan data pribadi dapat menimbulkan kerugian besar baik bagi pemerintah maupun bagi para pemilik data. Jual beli informasi data pribadi tanpa persetujuan pemilik data merupakan bentuk

\footnotetext{
${ }^{36}$ Richardus Eko Indrajit, et.al., e-Government In Action (Ragam Kasus Implementasi Sukses di Berbagai Belahan Dunia), Andi, Yogyakarta, 2005, hlm. 93.

37 National Information Resources Service, Background of the establishment, <http://www.nirs.go.kr/ eng/about/about 02.jsp> , diakses pada 22 Oktober 2020.

38 Ministry of the Interior and Safety, Organizational Chart, < $\underline{\text { https://www.mois.go.kr/eng/sub/ }}$ a02/organChart/screen.do >, diakses pada 22 Oktober 2020.

${ }^{39}$ Hayat, Kebijakan Publik (Evaluasi, Reformasi, dan Formulasi), Intrans Publishing, Malan, 2018, hlm. 84.
} 
kejahatan yang paling bahaya apalagi bila ruang lingkup jual beli nya sudah ditingkat internasional. Kebocoran kemanan data sederhana saja sudah dirasakan dampak ketidaknyamanannya seperti kebocoran data pribadi mengenai nomor telepon yang diikuti dengan juga dengan kebocoran informasi nama lengkap pribadi seseorang pengguna nomor telepon tersebut. Kepercayaan masyarakat kepada pemerintah akan sangat mempengaruhi keberhasilan dari penerapan $e$ government. Sentralisasi data akan dapat mempermudah memperhatikan faktor keamanan data masyarakat. Dengan adanya sentralisasi data, sistem informasi akan menjadi terpadu dan memiliki prosedur pengumpulan data yang pasti. Sehingga perbaikan pelayanan publik tidak hanya berfokus pada perbaikan efektivitas dan efisiensi saja tetapi pelayanan publik juga harus dapat memenuhi hak-hak dasar penduduknya.

Di Indonesia selama ini pengaturan terkait perlindungan data pribadi hanya sebatas bagian dari undang-undang lainnya. Beberapa undang-undang yang didalamnya terdapat pengaturan mengenai perlindungan data pribadi antara lain:40

a. Undang-Undang Nomor 10 Tahun 1998 tentang Perbankan, pada undangundang ini disebutkan dalam Pasal 40 bahwa bank diwajibkan untuk merahasiakan keterangan mengenai nasabah penyimpan dan simpanannya, kecuali dalam hal-hal tertentu yang dibolehkan.

b. Undang-Undang Nomor 36 Tahun 1999 tentang Telekomunikasi, pada Pasal 22 undang-undang telekomunikasi dijelaskan bahwa adanya larangan untuk melakukan akses ke jaringan dan/atau jasa telekomunikasi attau telekomunikasi khusus secara tanpa hak, tidak sah, atau dengan manipulasi.

c. Undang-Undang Nomor 8 Tahun 1999 tentang Perlindungan Konsumen, berdasarkan Pasal 2 undang-undang perlindungan konsumen berdarkan dengan asas manfaat, keadilan, keseimbangan, keamanan, dan keselamatan.

d. Undang-Undang Nomor 39 Tahun 1999 tentang Hak Asasi Manusia, dalam Pasal 29 ayat (1) undang-undang ini diakui hak setiap orang atas perlindungan diri pribadi, keluarga, kehormatan, martabat, dan hak miliknya.Serta pada Pasal 32 disebutkan bahwa kemerdekaan dan rahasia dalam hubungan komunikasi melalui sarana elektronik dijamin, kecuali atas perintah hakim atau kekuasaan yang lain yang sah sesuai dengan ketentuan perundangan.

e. Undang-Undang Nomor 23 Tahun 2006 tentang Administrasi Kependudukan, pada Pasal 2 undang-undang ini menjamin hak setiap penduduk untuk memperoleh perlindungan atas data pribadi, kepastian

40 Sinta Dewi Rosadi, Cyberlaw Aspek Data Privasi Menurut Hukum Internasional, Regional, dan Nasional, Refika Aditama, Bandung, 2015 hlm. 94-112. 
hukum atas kepemilikan dokumen serta informasi mengenai hasil pendaftaran penduduk dan pencatatan sipil atas dirinya dan/atau keluarganya. Pada Pasal 8 ayat (1) Huruf e, kewajiban instansi pelaksana melaksanakan urusan administrasi kependudukan yang diantaranya meliputi menjamin kerahasiaan kependudukan yang diantaranya neliputi menjamin kerahasiaan dan keamanan data atas peristiwa kependudukan dan peristiwa penting.

f. Undang-Undang Nomor 11 Tahun 2008 tentang Informasi dan Transaksi Elektronik. Pada Pasal 26 ayat (1) dijelaskan bahwa kecuali ditentukan lain oleh peraturan perundang-undangan, pengguna setiap informasi melalui media elektronik yang menyangkut data privasi seseorang harus dilakukan atas persetujuan orang yang bersangkutan. Sistem elektronik dalam undang-undang ini termasuk e-government.

g. Undang-Undang Nomor 14 Tahun 2008 tentang Keterbukaan Informasi Publik, Pasal 63 ayat (3) undang-undang keterbukaan informasi publik menyebutkan salah satu informasi publik yang tidak dapat diberikan oleh badan publik salah satunya adalah informasi yang berkaitan dengan hakhak pribadi.

h. Undang-Undang Nomor 36 Tahun 2009 tentang Kesehatan, dari Pasal 57 ayat (1) mengharuskan mengakui adanya hak setiap orang atas rahasia kondisi kesehatan pribadinya yang telah dikemukakan kepada penyelenggara kesehatan

i. Peraturan Pemerintah Nomor 71 Tahun 2019 tentang Penyelenggaraan Sistem dan Transaksi Elektronik pada Pasal 14 disebutkan Penyelenggara Sistem Elektronik wajib melaksanakan prinsip pelindungan Data Pribadi dalam melakukan pemrosesan Data Pribadi.

j. Peraturan Pemerintah Nomor 80 Tahun 2019 tentang Perdagangan Melalui Sistem Elektronik pada Pasal 58 dinyatakan bahwa setiap data pribadi diberlakukan sebagai hak milik pribadi dari orang atau pelaku usaha yang bersangkutan dimana setiap pelaku usaha yang memperoleh data pribadi wajib bertindak sebagai pengemban amanat dalam menyimpan dan menguasai data pribadi sesuai dengan ketentuan peraturan perundangundangan.

k. Peraturan Menteri Komunikasi dan Informatika Republik Indonesia Nomor 20 Tahun 2016 tentang Perlindungan Data Pribadi dalam Sistem Elektronik pada Pasal 5 ayat (1) disebutkan bahwa setiap Penyelenggara Sistem Elektronik harusmempunyai aturan internal perlindungan Data Pribadi.

Sudah banyak peraturan yang membahas mengenai perlindungan data pribadi. Namun, di Indonesia peraturan mengenai perlindungan data pribadi masih tersebar diberbagai tingkatan regulasi baik dalam undang-undang maupun peraturan pelaksananya dan belum memiliki peraturan perundang-undangan yang secara khusus mengatur mengenai perlindungan data pribadi yang membuat efektivitasnya dalam melindungi hak masyarakat terkait data pribadi 
masih diragukan. Sehingga masyarakat mengharapkan adanya kepastian hukum mengenai jaminan tentang perlindungan kemanan data pribadi ke pemerintah walaupun kepastian hukum merupakan hal sulit untuk dapat dituangkan dalam suatu hukum tetapi paling tidak harus diusahakan agar hukum tidak menjadi multitafsir dan saling tumpang tindih. ${ }^{41}$

Ada prisnip-prinsip yang harus dijunjung tinggi dalam melakukan perlindungan privasi masyarakat antara lain:42 pertama, harus proaktif, dimana perlindungan harus bersifat antisipasi sebagai bentuk pencegahan. Kedua, harus mengutamakan privasi pengguna. Ketiga, adalah perlindungan diintegrasikan ke dalam suatu desain tekonologi dengan mempertimbangkan berbagai aspek dan kemungkinan secara mendetal. Keempat, yaitu memiliki fungsi maksimal dimana untuk sistem setiap sistem elektronik harus tersedia standar tertentu. Kelima, harus memperhatikan keamanan total dari mula hingga akhir. Keenam, transparansi mengenai apakah teknologi yang ada sudah beroperasi sesuai dengan aturan yang telah disepakati dan diungkap ke publik. Ketujuh, adalah menghormati privasi pengguna dimana pemilik data pribadi dapat berperan aktif untuk mengelola data mereka.

Namun selain itu perlu diingat kembali bahwa pelaksanaan fungsi governing dalam governance tidak hanya menjadi kekuasaan atau urusan pemerintah saja. Fungsi governing dalam governance harus dilakukan bersama-sama oleh pemerintah dan institusi-institusi lain seperti LSM atau perusahaan swasta maupun warga negara. ${ }^{43}$ Selama ini pelayanan publik diselenggarakan secara monopolistik oleh birokrasi pemerintah sehingga tidak memiliki standar kinerja yang jelas. Birokrasi pelayanan cenderung menentukan standar yang rendah karena takut terbebani jika tidak berhasil memenuhi standar. Seharusnya standar pelayanan dibuat bukan hanya sebagai pedoman bagi penyelenggara layanan tetapi untuk para pengguna layanan tersebut agar menyadari hak-haknya dengan

\footnotetext{
${ }^{41}$ E. Fernando M. Manullang, Legalisme, Legalitas, dan Kepastian Hukum, Prenadamedia Group, Jakarta, 2016, hlm. 154.

42 Faiz Rahman dan Annisa Rahma Diasti, Bagaimana Mewnjudkan UU Perlindungan Data Pribadi yang Kuat di Indonesia, < https://theconversation.com/bagaimana-mewujudkan-uu-perlindungan-data-pribadi-yang-kuat-diindonesia-132498>, diakses 10 Juli 2020.

${ }^{43}$ Samodra Wibawa, Good Governance dan Otonomi Daerah, dalam Agus Dwiyanto (ed), Mewrijudkan Good Governance Melalui Pelayanan Publik, Gadjah Mada University Press, Yogyakarta, 2014, hlm. 77.
} 
mudah dan mengetahui seberapa jauh hak-haknya dipenuhi oleh para penyelenggara layanan. ${ }^{44}$ Namun apabila pengembangan sistem e-government diserahkan kepada pihak swasta, pemerintah perlu juga menerapkan standarisasi kebutuhan pengembangan agar apabila proyek pengembangan diberikan kepada beberapa pengembang akan dapat berjalan saling berkaitan.

Tidak adanya jaminan keamanan data pribadi dalam penerapan e-government akan sangat berpengaruh terhadap kepercayaan publik yang merupakan bagian dari tujuan untuk melakukan reformasi birokrasi. Jaminan berupa kepastian yang diatur dalam suatu hukum agar memiliki standar yang pasti mengenai kewajiban perlindungan yang harus dilakukan oleh penyelenggara e-government terhadap data pribadi masyarakat yang masuk ke dalam sistem e-government. Kepercayaan publik mencakup perihal kepercayaan masyarakat terhadap pemerintahan baik institusi, kebijakan, serta para pejabatnya, sehingga apabila institusi pemerintahan dapat berjalan efisien, adil, jujur, dan serta memenuhi segala janji yang diucapkan, masyarakat akan memiliki kepercayaan yang tinggi terhadap pemerintah. Tingginya kepercayaan publik akan mendukung jalannya pemerintahan dan segala kebijakan yang dibuatnya. Hubungan antara reformasi birokrasi dan kepercayaan publik parallel dengan hubungan antara mean dan end yang keterwujudannya sangat ditentukan oleh keseriusan pemerintah dalam melaksanakan reformasi birokrasi. ${ }^{45}$ Reformasi birokrasi dalam penerapannya harus dirancang agar dapat memperbaiki struktur birokrasi, membentuk budaya birokrasi yang berorientasi pada produktivitas dan melayanan, menjadikan kepentingan publik sebagai sentral dalam kehidupan birokrasi publik, serta membentuk aparatur yang berintegritas tinggi dan profesional. Perbaikan dan perkembangan pelayanan publik di segala unsurnya dapat menciptakan pelayanan publik yang cepat, prima, dapat diakses dimana saja dan kapan saja, serta dapat dipercaya oleh publik. Terdapat konsep pemikiran tentang kepercayaan publik terhadap e-government yaitu trust in e-government yang berarti seorang warga negara memiliki keyakinan dan harapan bahwa e-government akan memberikan layanan yang sesuai dengan kebutuhan dan keinginannya

\footnotetext{
${ }^{44}$ Agus Dwiyanto, Strategi Melakukan Reformasi Birokrasi Pemerintah di Indonesia, dalam Agus Dwiyanto (ed), Mewujudkan Good Governance Melalui Pelayanan Publik, Gadjah Mada University Press, Yogyakarta, 2014, hlm. 399.

45 Agus Dwiyanto, Mengembalikan Kepercayaan Publik Melalui Reformasi Birokrasi, PT Gramedia Pustaka Utama, Jakarta, 2011, hlm. 353.
} 
walaupun warga negara tersebut atas kinerja layanan e-government tidak memiliki kontrol. ${ }^{46}$

\section{Penutup}

Adapun dari uraian di atas dapat disimpulkan: Pertama, pelayanan yang diberikan oleh birokrasi pemerintah menuntut pertanggungjawaban yang tinggi. Pemerintah dalam menyelenggarakan layanan publik terlalu berfokus pada pertanggungajawaban formal yang memiliki banyak prosedur yang harus dilakukan secara manual yang menyebabkan pelayanan birokrasi berjalan lambat. Pelaksanaan sistem e-government di Indonesia akan berdampak banyak terhadap perubahan birokrasi yang dilakukan secara manual tersebut sehingga dalam memberikan layanan publik, pemerintah dapat menerapkan prinsip-prinsip good governance sesuai dengan yang ingin diwujudkan oleh negara Indonesia. Terselenggarannya good governance merupakan prasyarat bagi setiap pemerintahan untuk mewujudkan aspirasi masyarakat dan mencapai tujuan serta cita-cita bangsa dan bernegara. Oleh karena itu, guna pengembangan dan penerapan pertanggungjawaban pemerintah yang tepat sesuai dengan prinsip good governance sebagai sistem yang memiliki pengaruh untuk tercapainya pelaksanaan tata kelola pemerintah yang baik, maka yang dilakukan oleh pemerintah yaitu menerapkan sistem informasi dengan memanfaatkan kemajuan teknologi yaitu e-government. Kedua, penggunaan internet yang telah dimanfaatkan dalam berbagai bidang dapat berpotensi buruk pada penyalahgunaan yang dilakukan oleh pihak yang tidak bertanggungjawab. Pada umumnya manusia menginginkan privasi, keamanan, dan perasaan aman dalam hidup, termasuk juga dalam hal penggunaan internet. Tentunya sangat diharapkan bahwa apa yang dikerjakan dengan menggunakan teknologi internet bisa aman dan jauh dari kemungkinan untuk dirusak, dicuri, atau disalahgunakan oleh pihak yang tidak mempunyai hak. Oleh karena itu, dalam perkembangan pelaksanaan dari $e$ government diperlukan kerangka pengembangan yang jelas agar hasilnya juga maksimal sehingga pelayanan melalui sistem e-government yang diterapkan kedepannya memiliki keamanan yang cukup. Sudah banyak peraturan yang

46 Agus Purwanto dan Tony Dwi Susanto, "Pengaruh Dimensi Kepercayaan Terhadap Adopsi Layanan E-Government”, INFORM, Vol. 3 No. 1, 2018, hlm. 12. 
membahas mengenai perlindungan data pribadi. Namun Indonesia belum memiliki peraturan perundang-undangan yang secara khusus mengatur mengenai perlindungan data pribadi.

Sedangkan untuk sarannya: pertama, untuk dapat menciptakan sistem $e$ government yang dapat merwujudkan penyelenggaraan good governance, e-government harus memiliki visi yang jelas dalam pengembangannya serta pemimpin yang berkomitmen dalam pelaksanaanya. Kerjasama antar stakeholders baik pemerintah, masyarakat, ataupun pihak swasta sangat diperlukan agar secara bersama dapat mewujudkan layanan publik yang semakin professional dan berkualitas demi mewujudkan good governance. Kedua, di Indonesia diperlukan undang-undang khusus yang mengatur tentang perlindungan data pribadi yang didalamnya terdapat bagian yang memberikan jaminan atas kepastian perlindungan data pribadi dalam pelaksanaan sistem e-government dengan sanksi-sanksi yang memberatkan sangat diperlukan untuk mendukung pelaksanaan e-government guna mendapatkan kepercayaan dari masyarakat. Serta perlunya infrastruktur untuk mendukung manajemen sistem informasi agar sentralisasi data agar terdapat suatu bentuk prosedur pengumpulan data yang pasti guna meningkatkan faktor kemanan data. Dalam mendukung penyediaan infrastruktur yang dapat menmenuhi standar kemanan yang baik, pemerintah dapat bekerja sama dengan institusi non pemerintah yang bekerja secara profesional.

\section{Daftar Pustaka}

\section{Buku}

Brata, Roby Arya, Analisis Masalah Good Governance dan Pemerintahan Strategis, Pustaka Kemang, Jakarta, 2016.

Budhijanto, Danrivanto, Revolusi Cyberlaw Indonesia Pembaharuan dan Revisi UU ITE 2016, Refika Aditama, Bandung, 2016.

Dwiyanto, Agus, (ed)., Mewujudkan Good Governance Melalui Pelayanan Publik, Gadjah Mada University Press, Yogyakarta, 2014.

Dwiyanto, Agus, Mengembalikan Kepercayaan Publik Melalui Reformasi Birokrasi, PT Gramedia Pustaka Utama, Jakarta, 2011.

Hayat, Kebijakan Publik (Evaluasi, Reformasi, dan Formulasi), Intrans Publishing, Malang, 2018. 
Indrajit, Richardus Eko, et.al., e-Government In Action (Ragam Kasus Implementasi Sukses di Berbagai Belahan Dunia), Andi, Yogyakarta, 2005.

Laoly, Yasonna H., Birokrasi Digital, Pustaka Alvabet, Jakarta, 2019.

Manullang, E. Fernando M., Legalisme, Legalitas, dan Kepastian Hukum, Prenadamedia Group, Jakarta, 2016.

Muhadi (ed)., Hukum Administrasi dan Good Governance, Universitas Trisakti, Jakarta, 2012.

Rahayu, Amy Y.S., dan Vishnu Juwono.Birokrasi \& Governance Teori, Konsep, dan Aplikasinya, PT RajaGrafindo Persada, Depok, 2019.

Ramli, Ahmad M., Cyber Law \& HAKI dalam Sistem Hukum Indonesia, Bandung, Refika Aditama, 2004.

Rosadi, Sinta Dewi, Cyberlaw Aspek Data Privasi Menurut Hukum Internasional, Regional, dan Nasional, Refika Aditama, 2015.

Widodo, Joko, Akuntanbilitas dan Kontrol Birokrasi Pada Era Desentralisasi dan Otonomi Daerah, Insan Cendekia, Surabaya, 2001.

Young, James SL., Enabling Public Service Innovation in the 21st Century EGovernment in Asia, Times Editions, Singapore, 2003.

\section{Jurnal}

Cahyadi, Arif, "Penerapan Good Governance Dalam Pelayanan Publik", Jurnal Penelitian Administrasi Publik, Vol. 2 No. 2, 2016.

Heryana, Toni dan Sari Kartika Dewi, "Pengaruh Penerapan E-Government Terhadap Pelaksanaan Tata Kelola Pemerintahan Kabupaten Cianjur", Jurnal Riset Akuntansi dan Keuangan, Vol. 1 No. 1, 2013.

Irawan, Bambang, "Studi Analisis Konsep E-Government: Sebuah Paradigma Baru dalam Pelayanan Publik", Jurnal Paradigma, Vol. 2 No. 1, 2013.

Purwanto, Agus dan Tony Dwi Susanto, “Pengaruh Dimensi Kepercayaan Terhadap Adopsi Layanan E-Government", INFORM, Vol. 3 No. 1, 2018.

\section{Makalah/Pidato}

Retnowati, Nurcahyani Dewi dan Daru Retnowati. "Peranan E-Government Dalam Rangka Mewujudkan Good Governance Bagi Masyarakat", Seminar Nasional "Informatika" UPN "Veteran" Yogyakarta, Sabtu, 24 Mei 2008.

\section{Internet}

Aziz, Muhammad Faiz. Data Pribadi: Meneropong Kerangka Perlindungan Data Pribadi di Indonesia, < https://bahasan.id/data-pribadi-meneropongkerangka-perlindungan-data-pribadi-di-indonesia/>, diakses tanggal 9 Juli 2020. 
BBC News Indonesia, Data KTP elektronik diserahkan ke lebih 1.200 lembaga pemerintah dan swasta, bagaimana upaya menjamin privasi?, https://www.bbc.com/indonesia/indonesia-49103924>, diakses pada 17 September 2020.

Institute For Justice Reform, Menyelaraskan Kebijakan Data Terbuka dan Perlindungan Hak Atas Privasi, <https://icjr.or.id/menyelaraskankebijakan-data-terbuka-dan-perlindungan-hak-atas-privasi/>, diakses tanggal 16 Maret 2020.

IT Governance Indonesia, Tata Kelola Sistem Pemerintahan Berbasis Elektronik, $<$ https:/ /itgid.org/perpres-sistem-pemerintahan-berbasis-elektronik-egovernment-menjawab-tantangan-revolusi-4-0-untuk-wujudkan-tatakelola-pemerintah-dan-pelayanan-publik-transparan-dan-modern/>, diakses tanggal 16 Maret 2020.

Ministry of the Interior and Safety, Organizational Chart, <https://www.mois. go.kr/eng/sub/a02/organChart/screen.do>, diakses pada 22 Oktober 2020.

Moerdijat, Lestari. Perlindungan Data Pribadi, <http://lestarimoerdijat.com/ 2019/10/05/perlindungan-data-pribadi/>, diakses tanggal 16 Maret 2020

N, Sita. Penerapan Sistem E-Government di Indonesia, <https: / / www.goodnewsfromindonesia.id/2018/01/23/penerapansistem-e-government-di-indonesia>, diakses tanggal 11 Maret 2020.

National Information Resources Service, Background of the establishment, <http://www.nirs.go.kr/eng/about/about_02.jsp>, diakses pada 22 Oktober 2020.

Rahman, Faiz dan Annisa Rahma Diasti. Bagaimana Mewujudkan UU Perlindungan Data Pribadi yang Kuat di Indonesia, < https://theconversation.com/ bagaimana-mewujudkan-uu-perlindungan-data-pribadi-yang-kuat-diindonesia-132498>, diakses tanggal 10 Juli 2020.

Septiani, Maya. E-Government Sebagai Strategi dalam Meminimalisasi Penyebaran Covid19 dan Efektivitas Pelayanan Publik, <https://ombudsman.go.id/ artikel/ r/artikel--e-government-sebagai-strategi-dalam-meminimalisasipenyebaran-covid-19-dan-efektivitas-pelayanan-publik $>$, diakses tanggal 7 Juli 2020.

\section{Peraturan}

Grand Design Reformasi Birokrasi 2010-2025.

Undang-Undang tentang Perubahan atas Undang-Undang Nomor 23 Tahun 2006 tentang Administrasi Kependudukan, UU No. 24 Tahun 2013, Lembar Negara Nomor 232 Tahun 2013, Tambahan Lembar Negara Nomor 5475.

Undang-Undang tentang Pelayanan Publik, UU No. 25 Tahun 2009, Lembar Negara Nomor 112 Tahun 2009, Tambahan Lembar Negara Nomor 5038.

Instruksi Presiden tentang Kebijakan dan Strategi Nasional Pengembangan EGovernment, (Indonesia, Inpres No. 3 Tahun 2003). 